\title{
Accidents Caused by Spider Bites
}

\author{
Annelise Carla Camplesi ${ }^{*}$, Sthefani Soares Albernaz ${ }^{1}$, Karina Paes Burger ${ }^{1}$, \\ Carla Fredrichsen Moya-Araujo ${ }^{2}$ \\ ${ }^{1}$ School of Agriculture and Veterinary Science, Sao Paulo State University-UNESP, Jaboticabal, Brazil \\ ${ }^{2}$ School of Veterinary Medicine-FIO, Ourinhos, Brazil \\ Email: *annecamplesi@yahoo.com.br
}

Received 9 April 2014; revised 15 May 2014; accepted 22 May 2014

Copyright (C) 2014 by authors and Scientific Research Publishing Inc.

This work is licensed under the Creative Commons Attribution International License (CC BY).

http://creativecommons.org/licenses/by/4.0/

(c) (i) Open Access

\begin{abstract}
Accidents caused by spider bites occur in many countries and represent a public health problem due to their high severity and occurrence of fatal accidents. In Veterinary Medicine, the incidence of arachnidism is considered nonexistent in large animals, as their thick skin cannot be pierced, rare in cats and common in dogs, particularly due to their exploratory and curious habit, and the habitats of venomous animals, such as the arachnids, located close to urban areas. The aim of this review is to describe the characteristics and distribution of spiders, the mechanism of action of the venom, clinical signs, diagnosis and treatment of accidents caused by arachnids of genera Loxosceles sp., Phoneutria sp., Latrodectus sp., and suborder Mygalomorphae.
\end{abstract}

\section{Keywords}

\section{Arachnids, Clinical Signs, Diagnosis, Treatment}

\section{Introduction}

Spiders are the second largest order of arachnids, with more than 41,000 species described. Practically all of them are venomous, but only some of them have potential significance to human medicine and veterinary medicine, due to their venom toxicity, habitat of species, among other factors [1]. Arachnidism refers to intoxications after spider bites and was clinically described for the first time in 200's d.c. by Claudius Aelianus, who reported a serious accident caused by genus Latrodectus sp. (black widow) [2].

Accidents caused by spider bites have been seen in many countries and represent a public health problem due to their high severity and occurrence of fatal accidents [3]. In Brazil, the following genera are a concern to the World Health Organization: Loxosceles sp. (brown spider), Phoneutria sp. (wandering spider) and Latrodectus sp. (black widow), as they cause more severe accidents. However, the accidents caused by suborder Mygalo-

\footnotetext{
${ }^{*}$ Corresponding author.
} 
morphae (primitive spider) are also severe, although not clinically important, and its bite causes mechanical skin irritation and mucosa due to its urticating hairs used for defense [4].

Spiders of significance to veterinary medicine are genera Loxosceles sp. and Phoneutria sp. [2]. The incidence of arachnidism is considered nonexistent in large animals, as their thick skin cannot be pierced, rare in cats and common in dogs, particularly due to their exploratory and curious habit, and the habitats of venomous animals, such as the arachnids, located close to urban areas [5]. Despite the occurrence of accidents with dogs, it is not common to find cases reporting spider bites in animals [6].

According to the Ministry of Health [7], 72,685 cases of arachnidism in humans were reported in Brazil in 2013, but most of them (85\%) ignored or did not report the genus of spider that caused the accident. It shows that, despite the importance, complete reports of envenomation by spider bites are still scarce, which may indicate an underestimated national reality [8]. The highest incidence of arachnidism in Brazil is between October and April, affected by factors like temperature, humidity and reproductive cycle [5].

This review describes the characteristics and distribution of spiders, mechanism of action of the venom, clinical signs, diagnosis and treatment of accidents caused by arachnids of genera Loxosceles sp., Phoneutria sp. and Latrodectus sp., and suborder Mygalomorphae.

\section{Loxoscelism}

Spiders of genus Loxosceles sp. (brown spider), although not very aggressive, biting only when trapped, cause most accidents in Brazil [9]. Such high incidence of accidents is due to the fact that these spiders usually occupy human dwellings, hiding in furniture, rubbish and dark objects, easily biting in daily routine [10]. They are nocturnal, 1 - $4 \mathrm{~cm}$ length, brown and have a violin marking on the cephalothorax [11].

Accidents have been reported in several continents, as spiders of genera Loxoceles sp. are found in Africa, Asia, Australia, the Americas and Europe [12]. In Brazil, these spiders are commonly seen in the South and Southeast Regions, with Loxosceles gaucho the most frequent genus in the country [13]. This genus is the most frequent in cases of arachnidism in Brazil. In 2013, partial data show 3974 accidents caused by Loxosceles sp., 2591 by Phoneutria sp. and only 64 by Latrodectus sp. in humans [14].

Loxosceles venom has a substance named sphingomyelinase D that destroys cell membranes especially of the endothelium, red blood cells and platelets. In addition, this substance is a chemotatic factor to neutrophils, triggering an inflammatory process and promoting platelet adhesion and localized skin necrosis [15]. The accidents caused by this genus can be of high severity to humans and animals [5].

Spider bites may not cause pain immediately after the accident. Local effects of swelling, exhaustion and fever take around 12 hours to disappear [5]. The venom can make skin and systemic alterations-skin alterations are more common. Such alterations are influenced by the victim's health, obesity, site of the bite, inoculation dose, among other factors [16].

Skin lesions caused by Loxosceles sp. are slow and progressive, and involve: pain, edema, erythema, blister at the site of the bite, ecchymosis, rashes, burning, focal hemorrhagic lesions mixed with pale areas of ischemia and skin necrosis [15]. A report of loxocelism in a female dog made by Machado et al. [6] mentioned the manifestation of necrotic lesions with exudate and purulent hemorrhagic crusts, rashes and painful sensitivity observed after the lesions appeared, subcutaneous presence of bacteria, anemia and neutrophilic leukocytosis with left shift. Urine and serum biochemical exams presented results within normal ranges.

The systemic involvement, although not very frequent, can be the cause of the victim's death, especially with the presence of kidney failure, disseminated intravascular coagulation (DIC) e hemolysis [16]. Besides these systemic symptoms, the following can also be observed: fever, cephalalgia, myalgia, nauseas, blurred vision, diarrhea, sleepiness, irritability, anemia, jaundice, hemoglobinuria, leukocytosis, thrombocytopenia, rashes and general petechiae [15].

Since there are no pathognomonic lesions, the diagnosis of loxoscelism is based on clinical history and signs, especially: hemolytic anemia, leukocytosis with neutrophilia, thrombocytopenia, hyperbilirubinemia and, in case of kidney failure, increased creatinine and urea. It is essential to consider the geographical distribution and epidemiology of the spider [17]. In animals, when the skin lesion origin is unknown, the necrosis caused by the toxin can be misinterpreted as third-degree burn and the cutaneous-visceral condition as hemolytic anemia [18].

The specific therapy is used in humans only and it is based on anti-Loxosceles serum in case of evidence of hemolysis within maximum 24 hours after the bite; after this period, the nonspecific treatment should be used 
[17]. In short, the nonspecific treatment, used in both humans and animals, uses local and systemic corticosteroids, antibiotics, anti-inflammatory drugs, blood transfusion, rigorous lesion cleaning, cold compresses and local analgesics, if required [2].

In some cases, as that reported by [10], the surgical removal of dermatonecrotic lesion was essential for the recovery of a dog with loxoscelism. A report made by [19] described the utilization of blood transfusion in a case of loxoscelism in a human being to sooth the hemolysis situation. In addition, in another case report with a human being, Frezza [20] showed that the physical therapy after a repair surgery of dermatonecrotic lesions caused by a brown spider can help recover the amplitude of movements of the affected site.

\section{Phoneutrism}

Spiders of genus Phoneutria sp., known as wandering spider or banana spider, have a 5-cm body and up to 15-cm leg span, and they are larger than Loxosceles sp. and smaller than Mygalomorph spiders, with which they are often confused. They have eight eyes arranged in three lines, of light color, in heart or pear shape in the dorsal portion of the abdomen [2].

Wandering spiders are extremely aggressive and when they feel threatened, they assume an attack position, supporting its body on the four rear legs and lifting the two front legs, and they can jump up to $40 \mathrm{~cm}$. They are nocturnal and, during the day, they prefer less sunny places, like under plants and trees (they are usually found in banana trees and trees with foliage) and holes in the ground [13].

Spiders of genus Phoneutria sp. are found only in South America. Most accidents reported occur in Brazil the four main species in the country are: P. fera and P. reidyi in Amazonia, and P. keyserlingi and P. nigriventer in the Midwest, Southeast and South Regions of Brazil [21]. In the Southeast Region, the frequency of attacks is higher in March and April, the mating season, when spiders are more active and aggressive [9].

The venom of Phoneutria sp. is neurotoxic and activates the sodium channels, which promotes membrane depolarization, favoring the release of neurotransmitters, muscle contraction and nervous system activation [15].

Phoneutrism can be considered, in terms of severity, as: mild, in case of local pain, erythema and edema only; moderate, when the manifestations are not limited to the site of the bite, presenting also diaphoresis, cephalalgia, restlessness and hypothermia; and severe, when it involves intense pain, acute hypothermia arterial hypertension, vomiting, priapism, shock and acute pulmonary edema [13]. Bucaretchi et al. [21] demonstrated that most of total 422 (89.8\%) accidents with humans caused by Phoneutria sp. in a 9-year period in the city of Campinas had mild manifestations, and moderate and severe manifestations were more frequent in children (less than 10 years old) and old people (over 70 years old), who constitute the risk groups.

Laboratory exams can indicate, in severe cases, leukocytosis with neutrophilia, hyperglycemia and metabolic acidosis; however, as there is no pathognomonic lesion, anamnesis data and clinical exams are used to diagnose the accident [22].

The treatment uses systemic analgesia and, when local infiltration with lidocaine without vasoconstrictor is required, hot compress can help relieve the pain. Anti-arachnid serum is indicated only to humans in case of severe manifestation of clinical signs [23].

Blocking with local anesthetic is not always possible in animals, as most bites are in the muzzle, which is a place of difficult anesthetic block. This difficult block, combined with the fact that animals tend to develop systemic signs, makes prognosis difficult for the species [18].

\section{Latrodectism}

Spiders of genus Latrodectus sp. are small (1 to $2 \mathrm{~cm}$ ), of bright black color, and have a red marking in the shape of an hourglass on their abdomen [11]. Its popular name-black widow-is due to the frequent mates dead on their webs [13]. They are not aggressive, are gregarious, sedentary, occupy gardens, parks, grassy areas and hide in dwellings. Both genders have toxic venom, but the male, due to its small size (3 to $6 \mathrm{~mm}$ ), does not cause accidents [15].

The spiders of this gender are found in hot and arid regions, with mild winter, in all continents [11]. There are several black widow species in Brazil, but they correspond to the smallest portion of arachnidism (only 2\%) recorded in the country. Accidents in Brazil occur mostly in the Northeast Region [12].

The venom of black widows act on sensitive nerve terminations, activates the autonomous nervous system, releases cholinergic and adrenergic GABA neurotransmitters, and alters the pre-synaptic neuromuscular junction 
permeability to sodium and potassium [15].

The clinical manifestations in both humans and animals start with intense pain, hypersalivation, anxiety, fever, shivers, diaphoresis, thirst, nauseas, vomiting and hyperthermia followed by hypothermia [13]. Muscle alterations may occur, such as tremors, muscle contraction, fasciculation and general myalgia. The pain associated with abdominal muscle contraction may confuse zootoxin with acute abdomen [24]. Respiratory or cardiovascular failure seems to be the cause of deaths caused by latrodectism [11].

Laboratory alterations, such as leukocytosis with neutrophilia, lymphopenia, eosinopenia, hyperglycemia, hematuria, reduced concentration of albumin in urine and cardiologic alterations can help assess the patient's condition [17]. However, such alterations are nonspecific and depend on a clinical and epidemiological evaluation for the acute diagnosis [24].

The specific treatment (with anti-venom serum) is prescribed to moderate and severe accidents with humans and has been used in small animals [11]. The symptomatic treatment is based on the administration of local anesthetic block, systemic analgesics, myorelaxing diazepam, calcium gluconate and anxiolytics [25].

\section{Accidents Caused by Primitive Spiders}

Primitive spiders, also known as tarantulas, belong to the suborder Orthognatha (Mygalomorphae), are large and hairy, and live in natural holes [26]. They are frequently found in all regions of Brazil, and they have many species; however, they are less interesting to human medicine [13].

Bites of this spider are not usual, and when they occur, a lower degree of severity is involved [13]. The importance related to primitive spiders is associated with urticating hairs in the abdominal region used for defense [15].

The clinical signs of bites are mild and local, including especially short-duration pain and inflammation. These hairs can trigger a reaction of hypersensitivity expressed as a reaction of skin and high airways, such as: rashes, nausea, cough, dyspnea and bronchospasm [15].

There is no specific treatment for accidents caused by Mygalomorphae; when bites occur the therapy basically involves the administration of analgesics and anti-histamines [26] and, in case of allergic reaction caused by contact with the urticating hairs, the main practice is to use a corticosteroid ointment [13].

The health board of the São Paulo state describes that 23\% $(3104 / 13,496)$ of all cases involving venomous animals are caused by Arachnids. According to the Health Ministry, the southern region of Brazil recorded the highest number of accidents with spiders in the country, with 18,052 cases in 2011.

\section{Conclusion}

Strategies for prevention of accidents must be reassessed taking into account the ecological characteristics of each species, especially the ability of household infestation, and applied intensively in areas of occurrence of these species. In addition, awareness of the population is the key to reducing the morbidity of this type of accident.

\section{References}

[1] Oliveira, U. (2011) Diversidade e biogeografia de aranhas do Brasil: Esforço amostral, riqueza potencial e áreas de endemismo. Programa de pós-graduação em ecologia, conservação e manejo da vida silvestre. Universidade Federal de Minas Gerais, Belo Horizonte, 106 p.

[2] Nogueira, R.M.B. and Andrade, S.F. (2011) Manual de Toxicologia Veterinária. Editora Roca, São Paulo, 332.

[3] Silva, D.P. (2006) Análise do araneísmo e suas implicações epidemiológicas na cidade de Anápolis-GO. IV Seminário de iniciação cientifica. Universidade Estadual de Goiás-Unucet, Anápolis.

[4] Freitas, G.C.C., Oliveira, A.E., Farias, J.E.B. and Vasconcelos, S.D. (2006). Acidentes por aranhas, insetos e centopéias registrados no centro de assistência toxicológica de Pernambuco (1993-2003). Revista de Patologia Tropical, 35, 148-156.

[5] Spinosa, H.S., Gorniák, S.L. and Palermo-Neto, J. (2008) Toxicologia aplicada à Medicina Veterinária. Editora Manole, Barueri, 942.

[6] Machado, L.H.A., Antunes, M.I.P.P., Mazini, A.M., Sakate, M., Vailati, M.C.F. and Lourenço, M.L.G. (2009) Necrotic Skin Lesion in a Dog Attributed to Loxosceles (Brown Spider) Bite: A Case Report. Journal of Venomous Animals and Toxins Including Tropical Diseases, 15, 572-581. http://dx.doi.org/10.1590/S1678-91992009000300017 
[7] Ministério da Saúde (2013) Acidente por animais peçonhentos—Notificações registradas no Sistema de Informação de Agravos de Notificação. http://dtr2004.saude.gov.br/sinanweb/

[8] Brasil, T.K., Pinto-Leite, C.M., Almeida-Silva, L.M., Lira-da-Silva, R.M. and Brescovit, A.D. (2009) Aranhas de importância médica do estado da Bahia, Brasil. Gazeta Médica da Bahia, 79, 32-37.

[9] Reckziegel, G.C., Dourado, F.S., Igansi, C.N. and Caldas, E.P. (2011) Envenenamento por aranhas: Perfil epidemiológico no Brasil entre 2000 e 2010. Revista de Higiene Alimentar, 25, 194-195.

[10] Collacico, K., Chanquetti, A.M.S. and Ferrari, S. (2008) Acidente por loxosceles em cão-Relato de caso. Revista: Ensaio e Ciências, 2, 1-18.

[11] Osweiler, G.D. (1998) Toxicologia Veterinária. Editora Artes Médicas. Porto Alegre, 526.

[12] Chagas, F.B., D’Agostini, F.M. and Beltrame, V. (2010) Aspectos epidemiológicos dos acidentes por aranhas no Estado do Rio Grande do Sul, Brasil. Evidência: biotecnologia e alimentos, 10, 121-130.

[13] Auto, H.J.F. (2005) Animais Peçonhentos. Editora da Universidade Federal de Alagoas.

[14] Barraviera, B. (1999) Aspectos clínicos e terapêuticos dos acidentes por animais peçonhentos. Editora de Publicações Biomédicas, Rio de Janeiro, 246.

[15] Secretaria da Saúde (2014) (Aranhas) Acidentes. http://www.sesa.pr.gov.br/modules/conteudo/conteudo.php?conteudo=391

[16] da Silva, P.H., da Silveira, R.B., Appel, M.L., Mangili, O.C., Gremski, W. and Veiga, S.S. (2004) Brown Spiders and Loxoscelism. Toxicon, 44, 693-709. http://dx.doi.org/10.1016/j.toxicon.2004.07.012

[17] Saracco, A.S. and De Roodt, A.R. (2008) Loxoscelismo. Facultad de ciências médicas UNCuyo, Revista Médica Universitária, 1-10.

[18] Riboldi, E.O. (2010) Intoxicações em pequenos animais: Uma revisão. Monografia apresentada à Faculdade de Veterinária na área de toxicologia clínica como requisito para a obtenção da graduação em Medicina Veterinária. Porto Alegre.

[19] Silva, M.V., Crenitte, M.R.T., Furst, V.L. and Leitão, P.A. (1988) Emprego da exsangüineotransfusão em acidente loxoscélico humano, grave. Revista do Instituto de Medicina Tropical de São Paulo, 30, 259-263. http://dx.doi.org/10.1590/S0036-46651988000400002

[20] Frezza, R.M. (2007) Atendimento fisioterapêutico após cirurgia reparadora de lesões por aranha marrom: Relato de caso. Revista Brasileira em Promoção da Saúde, 20, 133-144. http://dx.doi.org/10.5020/18061230.2007.p133

[21] Bucaretchi, F., Deus-Reinaldo, C.R., Hyslop, S., Madureira, P.R., Capitani, E.M. and Vieira, R.J. (2000) A ClinicoEpidemiological Study of Bites by Spiders of the Genus Phoneutria. Revista do Instituto de Medicina Tropical de São Paulo, 42, 17-21.

[22] Cupo, P., Azevedo-Marques, M.M. and Hering, S.E. (2003) Acidentes por animais peçonhentos: Escorpiões e aranhas. Revista Medicina, Ribeirão Preto, 36, 490-497.

[23] Medeiros, S.B., Pereira, C.D.F.D., Ribeiro, J.L.S., Fernandes, L.G.G., Medeiros, P.D. and Tourinho, S.F.V. (2013) Integrative Review of Literature-Accidents Caused by Phoneutria nigriventer: Diagnosis and Nursing Interventions. Journal of Research Fundamental Care, 5, 467-474.

[24] Souza, A.R.B., Bührnheim, P.F. and Lima, C.S.C. (1988) Relato de um caso de latrodectismo ocorrido em Manaus, Amazonas, Brasil. Revista da Sociedade Brasileira de Medicina Tropical, 31, 95-98.

[25] Orduna, T.A. (2001) Accidentes provocados por ofidios, arañas y escorpiones. Curso Pre-Congreso: Toxicología Clínica (XII Congreso Argentino de Toxicología). Rosario. http://www.sertox.com.ar

[26] Vizzotto, C.S. (2009) Isolamento e caracterização de compostos bioativos da peçonha da aranha caranguejeira Lasiodora sp. Programa de pós-graduação em Biologia Animal. Fundação Universidade de Brasília, Brasília. 